\title{
GEOGRAFICKÉ DIMENZIE TRÁVENIA VOLNÉHO ČASU DETÍ A MLÁDEŽE V MESTE NITRA
}

\author{
Lucia Mekys
}

\begin{abstract}
Leisure time of children and youths on the example of Nitra City analyzes the options of spending leisure time in the city. We focus on defining basic concepts of leisure time and tourism fields. We analyze results of the survey in the second part. The largest part is devoted to recent phenomena, which are shopping centers. We concerned also about the issue of traffic in shopping centers versus in city park and we put together a chart of activities which people spend the most of their leisure time. The purpose of this thesis is to analyze the possibilities of spending leisure time of Nitra city inhabitants and identify the main recreational areas of the city.
\end{abstract}

Keywords: leisure time, leisure time activities, tourism, shopping centre

\section{Úvod}

Vol'ný čas tvorí vel'mi významnú úlohu v živote každého z nás. Je to čast' dňa, kedy sa môžeme naplno venovat' činnostiam, ktoré nás obohatia, doplnia nám energiu vynaloženú zo seba počas práce i štúdia a určite sem zahŕňame aj čas, kedy rozvíjame svoju fantáziu, tvorivost' alebo si zdokonal'ujeme mysel' v dobrovol'nom vzdelávaní. Vol'ný čas potrebuje každý človek, a to bez ohl'adu na jeho vekovú kategóriu. Na vek človeka však určite treba prihliadat', pretože práve to ovplyvňuje výber činností, ktorými budeme tento čas napín̆at'.

V našom príspevku sa zameriame na skupinu detí a mládeže. Vol'ný čas nemusí byt' touto skupinou l'udí využívaný iba v pozitívnom zmysle. Ako príklad môžeme spomenút' experimentovanie $\mathrm{s}$ fajčením, drogami alebo vykonávanie činností, pri ktorých priamo ohrozujú seba aj iných. Deti a mládež treba preto viest' k správnym návykom už odmalička. Najväčší podiel pri výchove a formovaní generácie by mali mat' rodičia, no $\mathrm{v}$ súčasnosti zasahujú do ich životov aj inštitúcie, cez ktoré môžu rozvíjat' svoje schopnosti.

V súlade s rozpadajúcimi sa tradičnými hodnotami mladých l'udí treba podotknút', že dnešná mládež trávi svoj vol’ný čas úplne inak ako ich rovesníci pred 20 - 30 rokmi. Vyplýva to z doby, v ktorej žijeme. Kým v minulosti nebol dostupný mobilný telefón, internet a d’alšie vymoženosti, bez ktorých si nevieme svoj terajší život predstavit', v súčasnosti sa l'udia vel'mi orientujú na materiálne hodnoty. Služby a tovar sa stávajú nositel'mi určitého významu, a preto je dnešná spoločnost' označovaná ako „konzumná“. V súvislosti s týmto faktom vznikol vo svete nový fenomén nazývaný nákupné centrá. Svojou širokou škálou 
ponúkaných obchodných prevádzok, stravovacích a zábavných zariadení, sa stali oblúbenou lokalitou, ktorá je často vyhl'adávaná a má svojich priaznivcov v každej vekovej kategórií. Efekt „všetko pod jednou strechou" nesie v sebe mnohé výhody. $\mathrm{Aj} \mathrm{z}$ tohto dôvodu sú nákupné centrá čoraz viac populárne a navštevované. Jednotlivé nákupné centrá sa však od seba odlišujú z hl'adiska rôznych kritérií. Či už je to vyššie spomínaná pestrost' prevádzok, poloha, dopravná dostupnost' alebo aj architektúra a celkový zásah do vzhl'adu krajiny navôkol. Stali sa konkurenciou aj pri realizovaní vol'ného času, napríklad voči prírode. Aj toto sú oblasti, ktorým sa budeme v nasledujúcich stranách venovat'.

\section{Vymedzenie základných pojmov}

Vol'ný čas - Francúzsky sociológ Dumazedier definoval pojem vol'ný čas ako súhrn činností, ktoré sú človekom vykonávané bud' za účelom oddychu, pobavenia alebo rozvíjania svojich znalostí, ktoré nie sú priamo súvisiace $\mathrm{s}$ povolaním. Tiež aj rozvíjania vlastnej účasti na spoločenskom živote a rovnako aj svojej slobodnej tvorivej schopnosti. Všetky tieto aktivity je však človek schopný naplno vykonávat' až vtedy, ked' je uvol’nený od svojich záväzkov voči rodine, práci i spoločnosti (Dumazedier, 1966).

Zaujímavé je aj chápanie vol’ného času Kaplana (1960), ktorý uvádza, že je to čas, $v$ ktorom je zahrnuté minimum nedobrovolných sociálno-rolových záväzkov. Vel'mi často býva spájaný so psychologickým vnímaním slobody a rovnako aj s príjemnými očakávaniami.

Z hl'adiska psychológie sa vol’ným časom detí a mládeže zaoberala aj Bieliková (2001), ktorá tvrdí, že sa jedná o čas mimo školského vyučovania, ktorý disponuje vel'kým množstvom aktivít. Deti a mládež ich dobrovol’ne môžu, ale nemusia praktizovat'.

Volný čas je dôležitý pre dospelého človeka a rovnako aj pre mládež a deti. Práve právo detí na vol'ný čas je popísané v Dohovore o právach diet'at’a z roku 1989, ktorý bol prijatý Organizáciou spojených národov (OSN). Šmahel (1994) uvádza, že pre deti a mládež sú pri správnom prežívaní vol'ného času dôležité slová „chcem a môžem“ a nemalo by byt' používané slovo „musím“.

Cestovný ruch - je charakterizovaný ako súhrn činností, ktoré úzko súvisia $\mathrm{s}$ cestovaním a pobytom l'udí mimo miesta svojho trvalého bydliska. Poväčšine sa tak deje v rámci vol'ného času. Táto činnost' si kladie za ciel' zdravie, odpočinok, poznávanie, tiež aj športové či kultúrne vyžitie, a teda získanie akéhosi komplexného zážitku (Gúčik, 2001).

Pri vzniku a rozvoji cestovného ruchu predstavoval vol'ný čas jeden zo základných predpokladov. Rovnako je to aj teraz, pretože ako tvrdí Gúčik a kol. (2004), vol'ný čas je tá čast' dňa, ktorá zostane človeku po odrátaní času, ktorý venuje uspokojovaniu svojich fyziologických potrieb (spánok, stravovanie, hygiena) a tiež zamestnaniu a starostlivosti o rodinu a domácnost'. 
Obr. 1: Vzt'ah vol’ného času a cestovného ruchu

Fig. 1: Connection between leisure time and tourism

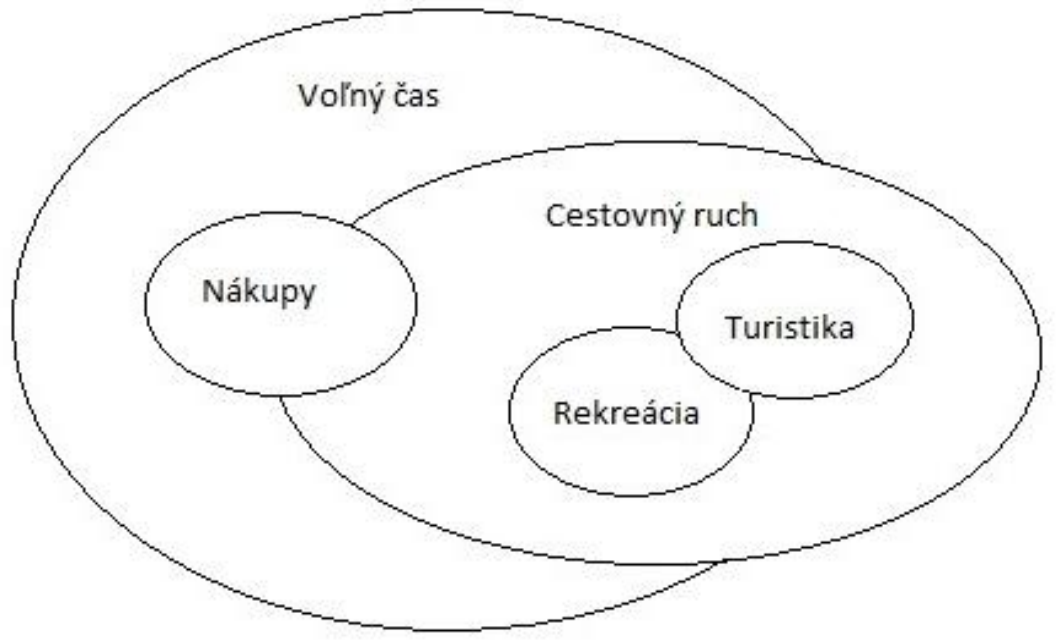

Zdroj: vlastné spracovanie

Na obr. 1 sme znázornili základné prepojenie cestovného ruchu a vol’ného času. Väčšinu cestovného ruchu realizujeme v rámci svojho vol'ného času. Nákupy sme umiestnili na rozhranie vol'ného času a cestovného ruchu z toho dôvodu, že za nákupnými možnost’ami sa dá cestovat' aj mimo miesta svojho bydliska, či už v rámci republiky alebo aj za hranice. $V$ cestovnom ruchu nachádzame prepojenie rekreácie a turistiky. Mnohí si myslia, že to znamená to isté, avšak nie je to tak. Rekreácia predstavuje jeden zo základných druhov CR. Turistiku chápeme ako súčast' športového cestovného ruchu. Ako príklad uvedieme horskú turistiku. Cestovný ruch však nie je vždy záležitost’ou vol'ného času. Výnimku tvoria činnosti a aktivity, ktoré môžu byt' súčast'ou práce a teda je kvôli nim potrebné vycestovat'. Tento druh môžeme pozorovat' aj $\mathrm{v}$ meste Nitra, kde sa $\mathrm{v}$ areáli výstaviska Agrokomplex konajú rôzne výstavy. Vtedy sa tu nachádza zvýšený počet l'udí z iných miest, prípadne aj susedných štátov. Najviac z Českej republiky, ked’že pri našich „bratoch“ nie je skoro žiadna rečová bariéra.

Deti a mládež - Dohovor o právach diet’at’a definuje diet'a ako l'udskú bytost' mladšiu ako 18 rokov, ak podl'a právneho poriadku, ktorý sa vzt'ahuje na diet'a, nie je plnoletost' dosiahnutá skôr (Dohovor o právach diet'at'a, 2017).

Mládež predstavuje sociálno-demografickú skupinu obyvatel'stva vo veku od 15 do 30 rokov. Táto skupina sa prejavuje špecifickými črtami, záujmami, požiadavkami a orientáciami, prostredníctvom ktorých je odlišovaná od iných vekových skupín. V tomto veku sa l'udia adaptujú do sveta práce, formujú svoje názory a zakladajú si rodiny (Smolík, 2010). 
Průcha a kol. (2003) definuje mládež ako sociálnu skupinu, ktorá je tvorená l'ud'mi, ktorých vek sa pohybuje medzi 15 až 25 rokom života. Títo l'udia už v spoločnosti nezohrávajú rolu detí, avšak spoločnost' im ešte nepridel'uje rolu dospelých. Vyznačujú sa špecifickým spôsobom myslenia a správania sa, iným systémom vzorov, noriem a hodnôt.

Nákupné centrum - Podl'a definície ICSC (International Council of Shopping Centres) sa pod tradičným nákupným centrom rozumie nehnutel'nost' slúžiaca na maloobchodné účely, prevádzkovaná ako jeden celok s celkovou prenajímatel'nou plochou väčšou ako 5-tisíc $\mathrm{m}^{2}$ a s minimálne 10 samostatnými jednotkami (Pokorný, 2009).

Spilková (2012) považuje nákupné centrum za architektonicky jednotný komplex predajní potravinárskeho i nepotravinárskeho charakteru, tiež obsahujúci stravovacie jednotky a prevádzky poskytujúce služby. Minimálna plocha nákupného centra je $5000 \mathrm{~m}^{2}$. Nákupné centrá bývajú lokalizované zväčša $\mathrm{v}$ prímestských zónach, avšak v poslednom čase sa $\mathrm{s}$ ich narastajúcou obl'ubou lokalizujú aj priamo do historického centra mesta. Výborným príkladom je nákupné centrum Galéria Mlyny Nitra (tab. 1).

Nákupné centrum predstavuje spoločenské miesto, ktoré môže l’ud’om dodávat' pocit istoty. Ak tu deti a mládež trávia svoj vol'ný čas, rodičia sa nemusia obávat' o ich bezpečie, nakol'ko každé takéto centrum je vybavené kamerovým systémom. Návštevníci sú tak chránení od kriminality a násilia. Musíme však skonštatovat', že ani kamerový systém a neustála kontrola SBS pracovníkov nedokážu zabezpečit' 100 percentnú bezpečnost'. Percento možnosti násilia je však na ovel'a nižšsej úrovni, ako keby sa mladí rozhodli vykonávat' svoje vol’nočasové aktivity v prírode. Ako tvrdí Coleman (2006), poskytnutie chráneného a bezpečného prostredia tvorí jeden z najdôležitejších faktorov pri vzniku nákupného centra.

Spilková (2012) uvádza, že teenageri predstavujú v dnešnej konzumnej spoločnosti dôležitú zložku z hl'adiska kúpnej sily. Tento fenomén označila pojmom „mall junkies". S týmto názorom sa nedá nesúhlasit', nakol'ko sami vidíme, že sledovanie módnych trendov sa stalo akousi súčastou života mladých a tiež aj spôsobom, ako sa l'ahšie zaradit' do spoločnosti alebo vybranej skupiny mladých l'udí, ktorí v čase dospievania podliehajú naozaj rôznym štýlom. Ak si zoberieme napríklad hudbu, vyčlení sa nám hned' niekol'ko skupín, do ktorých sa príslušníci zarad’ujú aj podl'a oblečenia (punk, emo, metal).

\section{Nákupné centrá v meste Nitra}

Spilková (2012) uvádza, že nakupovanie nemá za ciel’ iba kupovanie nových tovarov, ale stáva sa novým druhom odreagovávania, relaxácie a tým pádom sa jedná o spôsob trávenia vol'ného času. Tieto komplexy sú oblúbeným ciel'om víkendových rodinných výletov. Tento nový trend sa nazýva „fun shopping“ alebo aj ,experience shopping “. 
Tab. 1: Nákupné centrá v meste Nitra

Table 1: Shopping centers in Nitra city

\begin{tabular}{|l|r|}
\hline \multicolumn{1}{|c|}{ Názov nákupného centra } & \multicolumn{1}{c|}{ Vznik } \\
\hline 1. OC Centro Nitra - Akademická 1/A & 11.4 .2006 \\
\hline 2. Zábavno-obchodné centrum MAX - Chrenovská 30 & 2.12 .2006 \\
\hline 3. Obchodné centrum Galéria - Bratislavská 5 & 12.4 .2008 \\
\hline 4. OC Galéria Mlyny Nitra - Štefánikova 61 & 9.9 .2009 \\
\hline
\end{tabular}

Zdroj: vlastné spracovanie

\section{Možnosti trávenia vol'ného času v meste Nitra}

Mesto Nitra má bohatú históriu a mnoho krásnych miest v prírode, kam chodia l'udia často trávit' svoje vol'né chvíle a radi sa tam vracajú. Do tejto skupiny určite patrí napríklad Mestský park v Nitre, vrch Zobor, Kalvária, Nitriansky Hrad. Príroda však nie je jediné miesto, kam chodia deti a mládež vo svojom vol'nom čase, pretože toto mesto ponúka aj iné formy jeho trávenia. Sú to napríklad centrá vol'ného času. V Nitre máme 4 - Centrum vol'ného času Domino, Cirkevné centrum vol'ného času Hviezdoslavova 7, UPC - Univerzitné pastoračné centrum Pavla Straussa, Pribinova 7 a Fórum mladých, Štefánikova tr. 60.

Hovorí sa, že kol'ko jazykov vieš, tol'kokrát si človekom. S týmto názorom úplne súhlasíme. Ovládanie cudzích jazykov je v tomto svete vel'mi dôležité aj z hladiska uplatnenia sa na pracovnom trhu. V Nitre sa nachádza 17 jazykových škôl. Výučbu zabezpečujú aj zahraniční lektori, vd’aka ktorým žiaci nadobúdajú najpresnejšiu výslovnost'.

Ako sme však spomínali, mesto Nitra má bohatý kultúrno-historický potenciál a aj prírodné monumenty a preto musíme spomenút' Mestský park v Nitre. Park sa rozprestiera na ploche približne 20 hektárov. Je tvorený tromi čast’ami: Sihot', Spojovací park a Nový park. Najviac frekventovaná je čast' Sihot'. Pohl'ad z Mestského parku v Nitre ponúka výhl’ad na čast' hradieb Nitrianskeho hradu. Jeho história sa datuje od roku 871, teda v období rozpadania sa Vel'komoravskej ríše. Pýchou hradu je bezpochyby Katedrála sv. Emeráma, ktorej výnimočnost' spočíva $\mathrm{v}$ tom, že je najstaršou katedrálou na Slovensku. Ďalším atraktívnym miestom je určite Kluchov palác so sochou Atlanta, ktorý je pre Nitranov známy pod názvom Corgoň. O Corgoňovi kolujú medzi obyvatel'mi rôzne legendy. Niektoré ho opisujú, že bol mocným kováčom, ktorý chránil mesto počas tureckých vpádov a vlastnými rukami hádzal na útočiacich Turkov balvany. Iné hovoria o tom, že ak Corgoňovi chytíte palec na nohe a myslíte pri tom na nejaké želanie, splní sa.

Už pri príchode do mesta Nitra padne každému návštevníkovi do očí silueta vrchu Zobor. Zoborské vrchy tvoria najjužnejšiu čast' pohoria Tribeč. Súčast'ou 
územia sú rezervácie, ktoré boli vyhlásené na prísnu ochranu prítomných teplomilných lesostepných rastlinných a živočíšnych spoločenstiev - Národná prírodná rezervácia Zoborská lesostep a Prírodná rezervácia Žibrica. Turisticky najatraktívnejším územím $\mathrm{v}$ tejto lokalite je určite Pyramída, nachádzajúca sa pár minút chôdze od vrchu Zobor (588 m n.m.), z ktorej je nádherný výhl'ad na celé mesto. $\mathrm{V}$ minulosti tu bola $\mathrm{v}$ prevádzke lanovka, ktorá je dnes, bohužial', už v nefunkčnom dezolátnom stave. Výlet na Zobor chápu niektorí l'udia ako možnost' strávenia príjemných chvíl' v tichej prírode a niektorí to berú ako možnost' športového vyžitia. Pešo trvá vychádzka od liečebného ústavu na vrchol okolo 50 minút vol'ným tempom. Je vel'mi časté, že tu stretávame vel'ké množstvo cyklistov, kedy im tento výlet svižným tempom trvá ovel’a menej.

\section{Trávenie vol’ného času detí a mládeže v meste Nitra}

V našom výskume sme v meste Nitra anketovali spolu 200 respondentov. Z tohto celkového počtu prevažovali ženy - 113, čo tvorilo 56,5 \%. Zvyšných 43,5 \% predstavovalo 87 mužov.

Ked'že našou ciel'ovou skupinou sú deti a mládež, vytvorili sme si 4 hlavné kategórie. Začali sme najnižším vekom 6 až 9 rokov, no podarilo sa nám získat' iba 4 respondentov, nakol'ko práca s touto vekovou skupinou bola dost' náročná. Tvorila iba $2 \%$ z celkového počtu. Nasledovala veková skupina 10 až 14 rokov, oslovili sme 42 l'udí a tvorilo to $21 \%$ z našej vzorky opýtaných. Skupina mladistvých vo veku od $\mathbf{1 5}$ do 20 rokov predstavovala 34,5\%, presne 69 opýtaných. Najpočetnejšou skupinou boli obyvatelia vo veku od 21 do 26 rokov, presne 85 respondentov a tvorili až $42,5 \%$ z celkového počtu. Myslíme, že práve skupina $\mathrm{v}$ tejto vekovej kategórií dokáže utvorit' najobjektívnejší pohl'ad na správanie sa mládeže $\mathrm{v}$ nákupných centrách a tvorili vel'kú čast' návštevníkov, takže bolo najjednoduchšie zohnat' respondentov práve v tomto veku.

Dotazník začal krátkym vyplnením osobných údajov, pričom bola zachovaná anonymita respondentov.

Úvodná otázka sa týkala činností, ktorými si opýtaní najradšej vypĺn̆ajú svoj vol'ný čas. $V$ tejto otázke bolo možné označit' viacero možností, čím nám vzniklo 669 odpovedí. Ako môžeme vidiet' v grafe 1, škála činností bola naozaj pestrá.

$\mathrm{Na}$ základe percentuálneho vyjadrenia vidíme, že najvyšší podiel získala odpoved' - trávenie vol'ného času doma a to hraním počítačových hier alebo vyhl'adávaním dát na internete. Tvorilo ju 167 odpovedí, čo predstavovalo $25 \%$ z celkového počtu odpovedí. Je to naozaj vel'mi vysoké číslo a stojí za zamyslenie, či je to tak správne. Druhou najčastejšou odpoved’ou bola práve návšteva nákupného centra, ktorá bola uvedená v 118 odpovediach a tvorila 17,6\% z celkového počtu odpovedí. Je to tiež dost' vysoké číslo a práve skúmaním tohto fenoménu sa budeme aj v nasledujúcich otázkach podrobnejšie zaoberat'. 
Graf 1: Možnosti trávenia vol'ného času

Graph 1: The options of leisure time in Nitra City

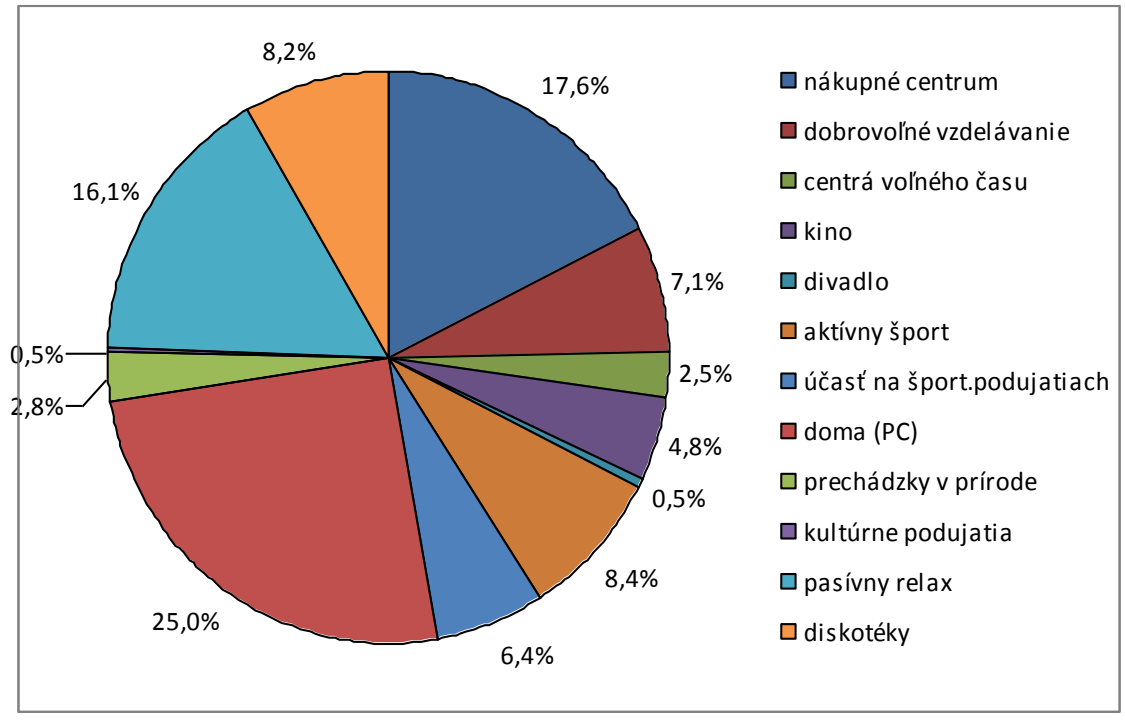

Zdroj: vlastné spracovanie na základe dotazníkového prieskumu

Ďalšou vol'bou respondentov bol pasívny relax, čo predstavuje oddych bez akéhokol'vek fyzického zat’aženia. Myslíme tým napríklad ležanie $\mathrm{v}$ posteli a počúvanie hudby. Túto formu trávenia vol'ného času sme zaznamenali v 108 odpovediach, čo predstavuje $16,1 \%$ z celkového počtu odpovedí. Od bezstarostného oddychu prechádzame $\mathrm{k}$ aktívnemu životu, teda $\mathrm{k}$ možnosti šport. Vykonávanie tejto činnosti sme zaznamenali v 56 odpovediach, teda 8,4\% $\mathrm{z}$ celkového počtu odpovedí.

Prekvapivé bolo, že iba 17 odpovedí, ktoré tvorili $2,5 \%$ z celkového počtu odpovedí, predstavovali návštevu centier vol'ného času. Namiesto rozvíjania svojej fantázie a sociálnych kontaktov sa deti radšej zavrú doma a trávia svoj čas na internete. Najmenšie percento záujmu, iba $0,5 \%$ dostali odpovede divadlo a kultúrne podujatia, ktoré boli uvedené iba $\mathrm{v} 3$ odpovediach.

V nasledujúcej otázke nás zaujímalo, akú štruktúru usporiadania obchodov návštevníci preferujú. Jednoznačnou vol'bou respondentov vyhrali vel'ké nákupné centrá. Tieto vel'ké komplexy obchodov preferuje až 166 opýtaných $(83 \%) .26$ odpovedí (13\%) bolo označených pri možnosti menšie obchodné jednotky, ktorými sme mysleli napríklad Pešiu zónu alebo obchody, ktoré sú rozmiestnené samostatne. Iba 8 l’udí (4\%) zvolilo ako oblúbenú formu menšie obchodné domy.

Vzhl'adom na jednoznačnú obl'ubu nákupných centier sme zist'ovali, ktoré centrum je pre deti a mládež najviac atraktívne (graf 2). 
Graf 2: Obl'úbenost' nákupných centier

Graph 2: Favor of shopping centers

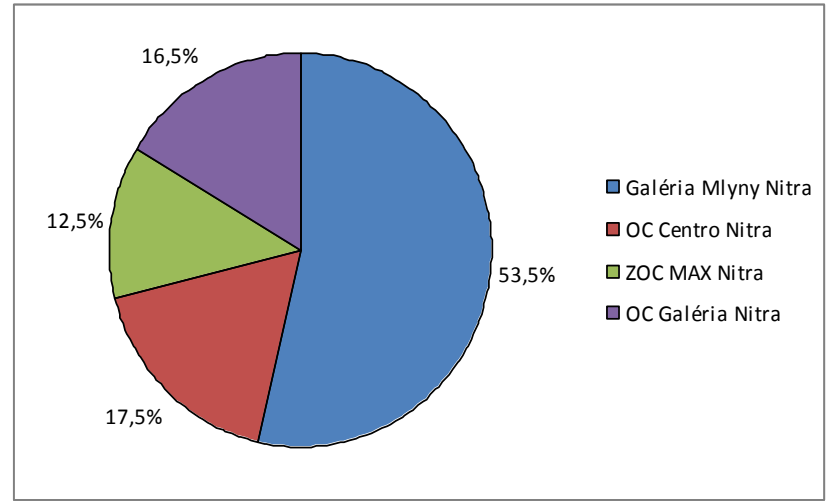

Zdroj: vlastné spracovanie na základe dotazníkového prieskumu

Pri tejto otázke sme sa dočkali výraznej prevahy OC Galérie Mlyny Nitra, ktorú za svoje najoblúbenejšie nákupné centrum označila nadpolovičná väčšina opýtaných, a to presne 107 l'udí, čo tvorí 53,5\%. Na druhom mieste skončilo OC Centro Nitra, ktoré označilo 35 l'udí $(17,5 \%) .33$ respondentov $(16,5 \%)$ rado navštevuje OC Galéria Nitra. Najmenej populárne je ZOC MAX Nitra, ktoré je pre mladých atraktívne hlavne kvôli kinu a označilo ho 25 l'udí (12,5\%).

Od nákupných centier prechádzame d’alej práve $\mathrm{k}$ protikladu, teda $\mathrm{k}$ prírode ako miestu trávenia vol'ného času. Zaujímalo nás, ako často ju navštevujú opýtaní $\mathrm{v}$ letných mesiacoch. Odpovede na túto otázku nájdeme v grafe 3.

Graf 3: Návštevnost' mestského parku

Graph 3: Visit rate of city park

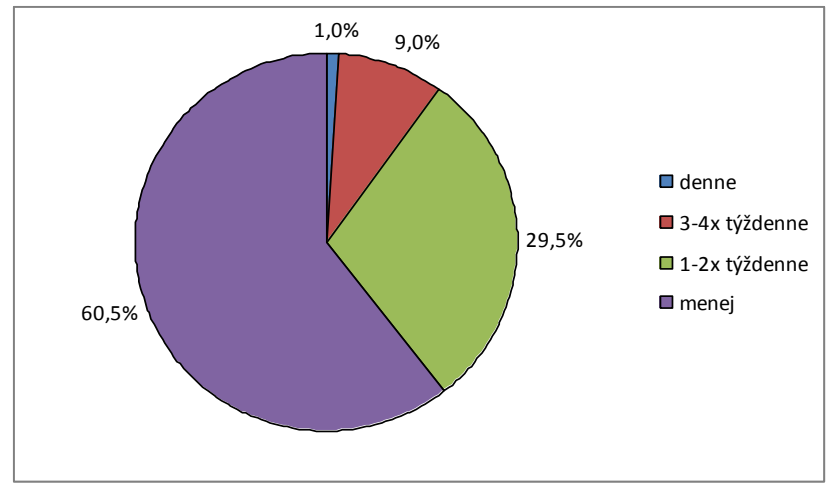

Zdroj: vlastné spracovanie na základe dotazníkového prieskumu 
Bohužial', až 121 respondentov (60,5 \%) úprimne priznalo, že aj napriek peknému počasiu navštevuje prírodu menej ako raz za týždeň. Najviac l'udí ju navštevuje 1-2x týždenne, čo označilo 59 opýtaných (29,5 \%), 18 l’udí (9 \%) sem chodí 3-4x týždenne a iba 2 odpovedali že ho navštevujú denne $(1 \%)$ a to za účelom aktívneho športu.

Nás teda zaujímalo, ako trávia deti a mládež čas strávený v mestskom parku. Najviac priaznivcov získala odpoved' posedenie s priatel'mi, čo uviedlo 119 l'udí $(59,5 \%)$ z celkového počtu opýtaných. Je to dané určite tým, že sme oslovovali iba mladú generáciu. Na druhom mieste je možnost' šport. Hlavne za touto aktivitou do prírody chodí 48 opýtaných (24\%) a na prechádzku prichádza 29 respondentov (14,5\%). Vel'mi malú oblúbenost' má činnost' hry s diet'at'om na detskom ihrisku, ktorú označili iba 4 respondenti $(2 \%)$ a výhradne za účelom pozorovania zvierat sem nechodí cielene nikto. Výsledky sú jednoznačne ovplyvnené tým, že sme anketovali iba deti a mládež, ktoré ešte nemali vlastné deti a tým pádom skončili práve vyššie spomínané aktivity na poslednom mieste.

Ako posledné nás zaujímala otázka kde sme sledovali, či l’udia súhlasia s názorom, ktorý hovorí, že keby neboli vystavané nákupné centrá, tak by l'udia trávili viac svojho vol'ného času v prírode. Až 143 l'udí súhlasilo (71,5\%). 57 respondentov s týmto názorom nesúhlasí $(28,5 \%)$.

\section{Záver}

V našom príspevku sme poukázali na trávenie vol’ného času detí a mládeže v meste Nitra. Zároveň sme analyzovali protiklad prírody a novodobého fenoménu nákupných centier. $\mathrm{Na}$ základe vyhodnotenia nášho výskumu môžeme skonštatovat', že nákupné centrá sa zapísali do životov detí a mládeže vel'mi vysokou mierou. Tento názor sa potvrdil aj na základe zistenia, že mládež si myslí, že keby neexistujú nákupné centrá, tak by bola príroda ovel'a viac navštevovaná. Kým v minulosti mala z hl'adiska nákupných možností najdôležitejšie postavenie pešia zóna, dnes už túto rolu $\mathrm{s}$ prehl'adom zastávajú nákupné centrá. Tieto komplexy v sebe zahŕňajú stravovacie, nákupné i zábavné možnosti pod jednou strechou a obyvatelia nemusia strácat' čas presunom cez mesto. Komfort návštevníkov umocňuje aj fakt, že kým obchodné jednotky na pešej zóne sú otvorené maximálne do 18 . hodiny, nákupné centrá ich vítajú až do 21 . hodiny. Potešujúce je aspoň zistenie, že v letných mesiacoch je mladými l'ud'mi navštevovaná pomerne často. Ked’že nákupné centrá zasiahli do životov väčšiny l'udí dost' vysokou mierou, zostáva nám iba dúfat', že ich budovaním sa budú aj nad’alej napĺn̆at' požiadavky obyvatel'ov a zároveň sa zvýši aj celková úroveň a atraktivita daného mesta. 


\section{Literatúra}

BIELIKOVÁ, M. 2001. Životný štýl mládeže vjednotlivých krajoch SR. 1. vyd. Bratislava : Ústav informácií a prognóz školstva, 2001. 61 s. ISBN 80-7098284-5.

COLEMAN, P. 2006. Shopping environments, evolution, planning and design. Oxford, Burlington: Architectural Press, 2006.

DOHOVOR O PRÁVACH DIEŤAŤA. 2017. [cit.2017-17-04]. Dostupné na internete: http://www.unicef.sk/dokumenty/materialy-na-stiahnutie/advocacy/ dohovor_o_pravach_dietata.pdf

DUMAZEDIER, J. 1966. Vol'ný čas. In Sociologický časopis. roč. 2, č. 4, s. 443447.

GÚČIK, M. 2001. Cestovný ruch pre obchodné a hotelové akadémie. Bratislava : SPN, 2001. 105 s. ISBN 8008030712.

GÚČIK, M. a kol. 2004. Krátky slovník cestovného ruchu. 1. vyd. Banská Bystrica : Slovensko-švajčiarske združenie pre rozvoj cestovného ruchu, 2004. 175 s. ISBN 80-88945-73-9.

KAPLAN, M. 1960. Leisure in Amerika: A Social Inquire. New York : John Wiley and Sons, 1960.

POKORNÝ, J. 2009. [cit. 2017-29-03]. Dostupné na internete: http://www. stavebne-forum.sk/sk/print/13576/po-patrocnom-raste-pokles-vystavby-nak upnych-centier/.

PRŮCHA, J. a kol. 2003. Pedagogický slovník. Praha : Portál, 2003.

SMOLÍK, J. 2010. Subkultury mládeže. Uvedení do problematiky. Praha: Grada, 2010. ISBN 978-80-247-2907-7.

SPILKOVÁ, J. 2012. Geografie maloobchodu a spotřeby. Praha : Nakladatelství Karolinum, 2012. 245 s. ISBN 978-80-246-1951-4.

ŠMAHEL, I. 1994. Osobnost a volný čas - teoretické základy výchovy ve volném čase. Brno, 1994. 72 s. ISBN 80-9683-7-8.

\section{GEOGRAPHICAL DIMENSIONS OF LEISURE TIME OF CHILDREN AND YOUTHS ON THE EXAMPLE OF NITRA CITY}

\section{Summary}

The options of spending leisure time of children and youths in the Nitra city were analyzed. We tried to point out the leisure time of children and youth in Nitra city, precisely the opposite phenomenon of nature and modern shopping centers. Based on the evaluation of our research, we found that shopping centers were enrolled in the lives of children and youth in very high rate. This view was also confirmed by the finding that young people think, if there were no shopping centers, the countryside would be more visited. While in the past, shopping 
opportunities were mostly based in the pedestrian zone, now this role, with an overview, hold shopping centers. These complexes imply dining, shopping and entertainment options under one roof and customers do not have to waste time transferring through the city. Comfort of customers is enhanced by the fact that while the promenade in the pedestrian zone is open only till 6 p.m., shopping centers welcome them up to 9 p.m. Nature, therefore, came into the background. Pleasing is at least finding that in summer young people visit nature more often. Since shopping malls have pretty much affected lives of most people, it remains our only hope that they will continue to meet the requirements of the population while increasing the overall level and attractiveness of the city.

\section{Mgr. Lucia Mekys}

E-mail: luciamekys@gmail.com 